\title{
Ability of males of two theclini species (Lepidoptera: Lycaenidae) to discriminate between sexes and different types of females based on the colour of their wings
}

\author{
Michio IMAFUKU and TASUKU KITAMURA \\ Department of Biology, Graduate School of Science, Kyoto University, Sakyo, Kyoto, 606-8502, Japan; \\ e-mails: imafuku@kyoto.zaq.ne.jp; kitamuratasuku@yahoo.co.jp
}

Key words. Lepidoptera, Lycaenidae, wing colour, polymorphism, sexual discrimination, Chrysozephyrus smaragdinus, Neozephyrus japonicus

\begin{abstract}
Many territorial species of butterfly are sexually dimorphic in their wing colours, and males of such species frequently fight each other, probably attracted by the rival's wing colour. On the other hand, male behaviour should be directed to acquiring mates to increase their fitness, and thus should be sensitive to (usually cryptic) female wing colour. The present experiments aimed to determine whether the conspicuous male colour or cryptic female colour is more attractive to the territorial males of two lycaenid species, Chrysozephyrus smaragdinus and Neozephyrus japonicus. A pair of female and male wing models was presented simultaneously in the field to a male. The results indicate that the males of both species were preferentially attracted by the female wing model. In N. japonicus, in which the wing colour of females is polymorphic, males preferred particular types of female wings, in that they were more strongly attracted to the type-B model with a blue patch on the forewing than the type-O model, which lacked a blue patch.
\end{abstract}

\section{INTRODUCTION}

Conspicuous and sometimes brilliant colours of butterflies are thought to play a role in their intraspecific communication, especially in the location of mates by males (Silberglied, 1977, 1984). For mate acquisition, male butterflies are known to adopt two tactics, patrolling and perching or occupying a territory (Scott, 1973, 1974; Silberglied, 1984; Rutowski, 1997; Wiklund, 2003). Males of patrolling species fly around searching for potential mates and thus are expected to be sensitive to the wing colours of conspecific females. This has been shown for many species: Heliconius erato (Linnaeus) (Crane, 1955), H. melpomene (Linnaeus), H. cydno Doubleday (Jiggins et al., 2001), Argynnis paphia (Linnaeus) (Magnus, 1958), P. protodice Boisduval \& Leconte (Rutowski, 1981) and Eurema lisa (Boisduval \& Leconte) (Rutowski, 1977). Females tend to sit quietly on a leaf with their wings closed and males identify potential mates by the colour of the underside of the female's wing in Pieris rapae (Linnaeus) (Obara, 1970), Colias eurytheme Boisduval (Silberglied \& Taylor, 1978), Lycaeides idas (Linnaeus) (Fordyce et al., 2002) and Polyommatus icarus (Rottemburg) (Knüttel \& Fiedler, 2001).

On the other hand, males of territorial species usually settle on an extended shoot or the ground where there is a wide view of the surrounding area and respond to invading objects. The list of animals approached or inspected by a territorial Hipparchia semele (Linnaeus) male includes 21 species of butterflies, 2 species of moths, more than 22 species of other insects including coleopterans, hymenopterans, dipterans, neuropterans and orthopterans, and 4 species of birds (Tinbergen et al., 1942). Animals other than lepidopterans inducing such a response by territorial males of Pararge aegeria (Linnaeus) include dipterans and coleopterans (Davies, 1978), for Anartia jatrophae (Linnaeus) neuropterans (Lederhouse et al., 1992) and for $\mathrm{Hy}$ polimnas misippus (Linnaeus) weaver birds (Stride, 1956). A territorial male of Nymphalis antiope (Linnaeus) inspected birds, humans, light-coloured objects placed on a ledge and falling leaves, which they prodded two to three times before they reached the ground (Bitzer \& Shaw, 1983).

At a short distance, however, they may discriminate between invading objects, as they respond differently to them: in the case of non-conspecific butterflies and other insects territorial males undertake short inspection flights, spiral flights or chase conspecific males and unwilling, already mated conspecific females, and long courtship flights in the case of unmated females (Davies, 1978; Lederhouse, 1982; Cordero \& Soberón, 1990; Lederhouse et al., 1992).

How are the males able to discriminate between different objects? As far as the authors know, there are only two studies that have addressed this question. One demonstrated that territorial males of Hipparchia semele respond to darker paper models, independently of their hue (Tinbergen et al., 1942). This species is sexually monomorphic in wing colour. The other study on males of sexually dimorphic Hypolimnas misippus revealed they preferred female wings or female-coloured models (Stride, 1956, 1957). Utilization of wing colour for discrimination is thus most likely to occur in dimorphic species.

One problem with the use of wing colour in dimorphic species is the fact that females tend to be cryptic. When wing colour dimorphism occurs in territorial species, females are usually dull or cryptic, in contrast to males, 
which are conspicuous (Rutowski, 1997). The example of H. misippus mentioned above is exceptional, because this species is mimetic, with females having conspicuous orange wings. Thus, males of most species need to be able to find cryptic females.

Another problem that males face in mate-finding is their strong pugnacious propensity. Territorial males that are conspicuously coloured are likely to be easily detected at a long distance and be involved in aggressive interactions (Vane-Wright, 1984). Males frequently perform spiral or circling flights, which may reach heights of more than $30 \mathrm{~m}$ (Lederhouse, 1982). Males of some theclini species show circling flights at a frequency of 35 to 45 per 30 min (Takeuchi \& Imafuku, 2005a) and such flights may continue for over $20 \mathrm{~min}$ (Fujii, 1982). Male-male interactions are significantly extended when rivals are the typical conspicuous yellow in contrast to when rivals are a modified black (Lederhouse \& Scriber, 1996). Regardless of whether they display such aggressiveness or not, territorial males need to find females as the fitness of males is mainly dependent on locating and mating with females. When a territorial male comes across a situation where a conspicuous male and a cryptic female simultaneously appear, how does he behave? In this study, the question of whether wing colours play a role in mate detection by males of two theclini species was determined using wing models. In addition, as the females of one of the species studied is polymorphic, we also examined whether males have the ability to discriminate minor chromatic differences in the wing colour pattern of females.

\section{MATERIAL AND METHODS}

\section{Butterflies}

Two species of lycaenid butterflies, Chrysozephyrus smaragdinus (Bremer) and Neozephyrus japonicus (Murray), belonging to tribe Theclini, subfamily Theclinae, were investigated. They show conspicuous sexual dimorphism in wing colouration. The dorsal surface of the wings of the males in both species is a glittering green (Figs 1A left and 1C), which is a structural colouration (Imafuku et al., 2012), and basically dark brown in females.

Females of $C$. smaragdinus have a large orange patch on the forewing (Fig. 1A right), and those of $N$. japonicus show four types of colouration on the forewing: a blue patch (type B, Fig. 1D), a small orange patch (type A), both types of patch (type AB), or lack a patch (type O, Fig. 1E). The ventral wing colours are similar in the two sexes of both species: basically greyish brown with a white stripe running through the pair of wings on each side, and a small orange spot in the posterior corner of the hindwing (Figs 1B, F). The reflectance spectra of the wings of $C$. smaragdinus are reported elsewhere (Imafuku et al., 2002).

\section{Wing model}

To examine the effects of wing colours on males, wing models were devised. Separated wings were pasted on both sides of a thin plastic plate $(0.3 \mathrm{~mm}$ in thickness $)$ with the dorsal surface on one side and ventral surface on the other. A model was attached to a toothpick (60 $\mathrm{mm}$ long, $2 \mathrm{~mm}$ thick) which was inserted into the top of an aluminium tube (100 $\mathrm{mm}$ long) rotated by a motor. Models of the two sexes or different female types separated horizontally by a distance of $290 \mathrm{~mm}$ were simultaneously presented to a male in the field (Fig. 1A). Their rotation rates were synchro- nized using a timing belt. The rotation rate $(12.1 \pm 3.2 / \mathrm{s}, \mathrm{m} \pm \mathrm{SD}$, $\mathrm{n}=8$ ) was somewhat lower than the wingbeat frequencies of the butterflies $(20.9 \pm 4.2 / \mathrm{s}, \mathrm{n}=8$, for $C$. smaragdinus, $19.0 \pm 2.8 / \mathrm{s}, \mathrm{n}$ $=8$, for $N$. japonicus, determined using a high-speed video camera, HSV-500 $\mathrm{C}^{3}, \mathrm{Nac}$ ), as it was thought that butterflies could more easily perceive colours of objects at a lower rotation rate.

\section{Field experiments}

\section{C. smaragdinus}

Presentation experiments were carried out between 10:00 to 15:00 during the period when this species was active on 5 and 6 July 2002 (Takeuchi \& Imafuku, 2005b) in Kinasa Village, Nagano Pref. $\left(36^{\circ} 45^{\prime} \mathrm{N}, 138^{\circ} 00^{\prime} \mathrm{E}\right)$. In the field used in this study, there were two sites where males of this species preferred to establish a territory, which were approximately $30 \mathrm{~m}$ apart.

At each site, a pair of models was presented near the point where the male frequently alighted. When the models were rotated, the male either approached or did not. A butterfly on the wing was readily attracted. When the male approached either or both models at least once, the rotation was stopped and the position of the two models (to the left or right, viewed from the open space) was exchanged for a second presentation. Two presentations with different model positions constituted one test. Model position in the first presentation was alternated from one test to the next. All tests were recorded using a video camera at a rate of 60 frames/s (Handycam DCR-VX2100, Sony).

As this species is known to establish and use the same territory over many days (Takeuchi \& Imafuku, 2005b), after one test the male was captured and never released. The next test was made at the other site, and meanwhile another male usually invaded and occupied the first site.

\section{Neozephyrus japonicus}

The basic method was the same as above. The experiments were performed during the period this species was active, between 17:00 to $18: 30$, in a field in Ryugasaki, Ibaraki Pref. $\left(35^{\circ} 55^{\prime} \mathrm{N}\right.$, $140^{\circ} 10^{\prime} \mathrm{E}$ ) (Imafuku et al., 2006), on sexual discrimination at the end of June 2002 and female type discrimination from the end of June to early July in 2002 and 2011-2013.

In the field used for this study, there were many Alnus japonica (Thunberg) Steudel trees, a larval food plant, which yielded many butterflies of this species. During the period it was active, malemale interactions were very frequent, developing into circling flights (Imafuku et al., 2006). N. japonicus is said to be territorial (Shirôzu \& Saigusa, 1980; Fukuda et al., 1984), but males in this field frequently changed alighting points due to their high density, and in such cases the models were set in a place where males frequently passed by, usually near the surface of a tree or in a narrow space among trees.

Because the direction of rotation of the model affects the behaviour of approaching individuals of Argynnis paphia (Magnus, 1958), it was also included in our experiment. A pair of models were presented in such a way that in the first presentation, for example, the male model was on the left (L) and the models rotated clockwise (C) (presentation LC, the first letter indicating male model position and the second the direction of rotation), followed by presentations LA (left, anti-clockwise), RA (right, anticlockwise) and RC, which constituted one test. The two models presented were rotated in the same direction. Model position and rotation direction were randomized from one test to another.

When multiple tests were performed on one day, they were done at different sites (at least $5 \mathrm{~m}$ apart), or at different heights (2-3 $\mathrm{m}$ or $5-6 \mathrm{~m}$ from the ground). 

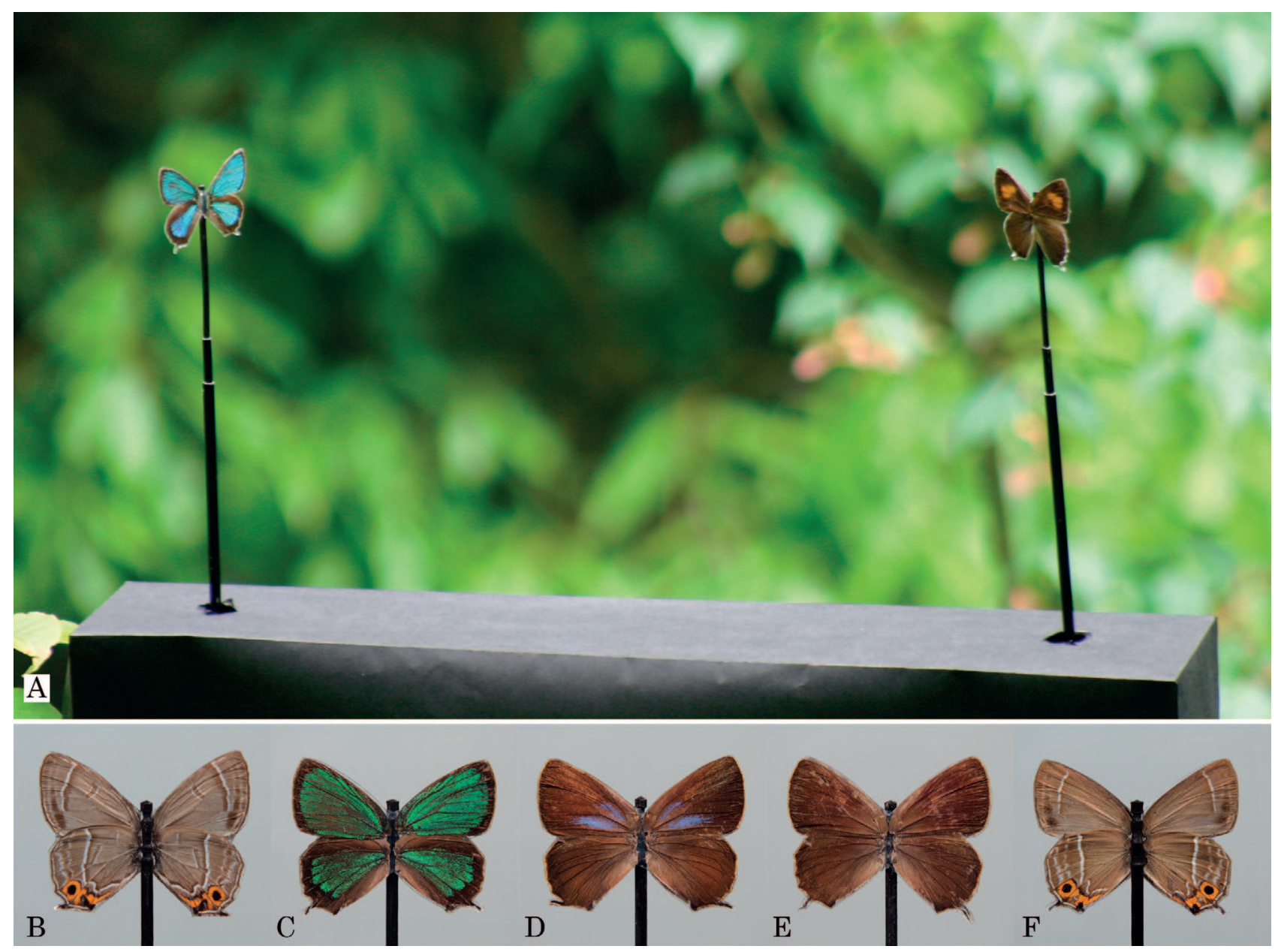

Fig. 1. A picture of a presentation experiment (top) and the wing models used (bottom). A - Male (left) and female (right) wing models of Chrysozephyrus smaragdinus attached to the top of aluminium tubes, which were synchronously rotated using a timing belt and two motors in the black box at the bottom. The dorsal surfaces of the models are shown. $\mathrm{B}$ - Ventral view of a $C$. smaragdinus male. C and F - Dorsal and ventral views of a Neozephyrus japonicus male, respectively. D and E - Dorsal views of type-B and type-O females of $N$. japonicus, respectively.

\section{Video analysis}

In video images, a butterfly approached one model, or two models (occasionally going back and forth between them). Analysis was made at the frame level. On the video screen, two transparent sheets, each with a circle of a radius of $50 \mathrm{~mm}$, were put, respectively, on the two models, with the centre of the circles on the thoraces of the model butterflies, and a frame in which any part of a butterfly was superimposed, such as a wing tip or thorax, within the circle was judged as showing an approach to the model.

Analyses were made of the first approach and staying time. The first approach was taken as that when a territorial male approached either of the models for the first time in the first presentation. The staying time was the total number of frames that showed the butterfly figure within the circle in a test. When a butterfly moved away and returned within one second, the record was regarded as continuous. In most cases, once a butterfly moved away it did not return within minutes.

\section{Statistics}

For the first approach, the numbers of individuals that firstly approached either of two models were compared between sexes or types using a binominal test. For the effect of sex, position and direction of rotation, the staying time was compared for the two models, using Wilcoxon's signed-ranks test. For these analyses, statistical software JMP, version 5.1.1 (SAS Institute), was used.

\section{RESULTS}

\section{Sexual discrimination}

For Crysozephyrus smaragdinus, a brilliant green male wing model and female wing model with an orange patch were compared in a total of 8 tests (Fig. 2A). In the first approach, five of eight territorial males approached the female wing model and three the male wing model, indicating no discrimination of sex by wing colour $(n=8, P>0.7)$. On the other hand, all eight males stayed significantly longer at the female model than the male model $(\mathrm{n}=8, \mathrm{Z}=$ 18.0, $\mathrm{P}<0.01)$. The position of models had no effect on the staying time of males $(\mathrm{Z}=7.0, \mathrm{P}>0.3)$.

For Neozephyrus japonicus, the female wing model of type B with a blue patch and green male wing model were compared in a total of 10 tests (Fig. 2B). In the first approach, eight males approached the female model and two males the male model $(n=10, P>0.1)$. The staying time of all the males was significantly longer at the female model 


\section{A Chrysozephyrus smaragdinus (sex)}
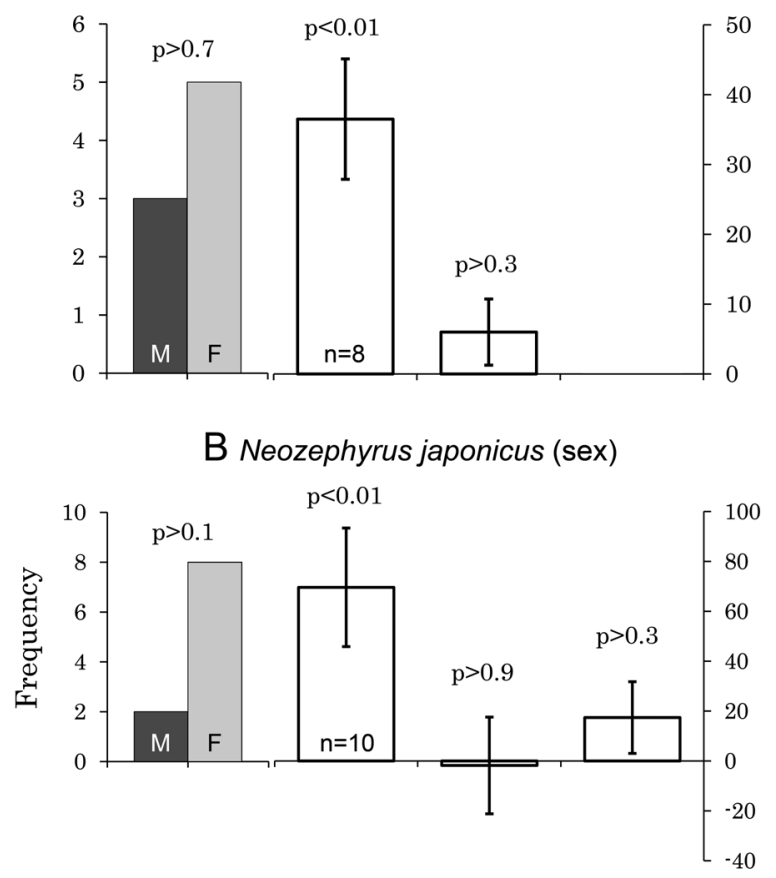

C Neozephyrus japonicus (type)

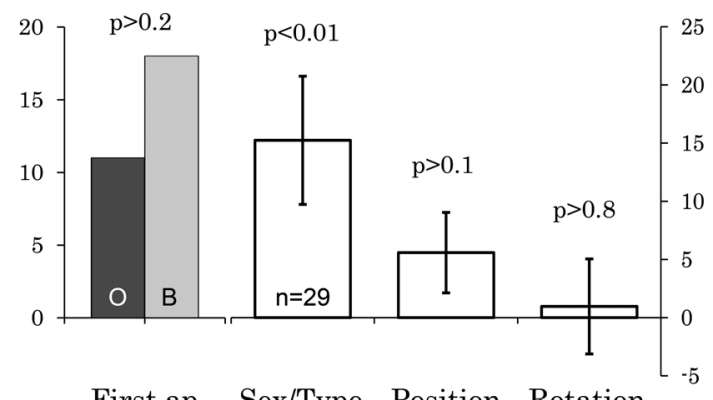

First ap. Sex/Type Position Rotation

Fig. 2. Frequency of the first approach (two left columns) and staying time (three right columns) for different models recorded for two theclini species. The two top graphs show the results of experiments on sex, and the bottom graph those on female type. Difference in staying time was calculated as females minus males for sexes (A \& B) and as type B minus type O for female types (C), as left minus right for position and the same relation (e.g., left model with anti-clockwise rotation) minus the reversed relation (e.g., right model with anti-clockwise rotation) for rotation. The numbers of individuals examined are shown at the base of the middle column. Vertical bars indicate standard errors. $\mathrm{M}$ - male; $\mathrm{F}$ - female; $\mathrm{O}$ - type $\mathrm{O}$; B - type B.

$(\mathrm{n}=10, \mathrm{Z}=27.5, \mathrm{P}<0.01)$. Neither position nor direction of rotation of the model had a significant effect on the staying time of males $(\mathrm{Z}=0.5, \mathrm{P}>0.9$ for position, $\mathrm{Z}=10.5$, $\mathrm{P}>0.3$ for rotation direction).

\section{Discrimination between different types of females}

As type-B and type-O females were the most prevalent in the population of $N$. japonicus in the field studied, these two types were used in the female type discrimination experiment. A total of 29 tests were performed (Fig. 2C).

Males of $N$. japonicus did not show a different response to the two different types of females in the first approach (n
TABLE 1. Spermatophore counts and number of individuals (in parentheses) of type-B and type-O females of Neozephyrus japonicus.

\begin{tabular}{cccccccccc}
\hline \multicolumn{3}{c}{ Date of collection } & & \multicolumn{2}{c}{ Type B } & & \multicolumn{2}{c}{ Type O } \\
\cline { 1 - 1 } \cline { 8 - 9 } 2000 & July & $22-24$ & & 1.80 & $(5)$ & & 1.50 & $(2)$ \\
2001 & July & $11-15$ & & 1.19 & $(21)$ & & 1.70 & $(10)$ \\
2002 & July & $1-2$ & & 0.44 & $(9)$ & & 0.50 & $(8)$ \\
& & $12-13$ & & 0.91 & $(11)$ & & 1.29 & $(7)$ \\
& & 24 & & 2.60 & $(5)$ & & 1.80 & $(5)$ \\
2003 & July & $17-20$ & & 1.33 & $(46)$ & & 0.88 & $(26)$ \\
2004 & June & $28-29$ & & 0.27 & $(11)$ & & 0.25 & $(4)$ \\
& July & $17-18$ & & 1.74 & $(35)$ & & 2.24 & $(17)$ \\
2005 & July & 10 & & 0.38 & $(16)$ & & 0.33 & $(3)$ \\
2009 & June & $27-29$ & & 0.82 & $(11)$ & & 0.25 & $(8)$ \\
\hline Total & & & & 1.18 & $(170)$ & & 1.19 & $(90)$ \\
\hline
\end{tabular}

$=29, \mathrm{P}>0.2)$. In contrast, 21 out of 29 males stayed significantly longer at the type- $\mathrm{B}$ model than type-O model $(\mathrm{n}=$ $29, \mathrm{Z}=121.5, \mathrm{P}<0.01)$. On the other hand, position and direction of rotation of the model had no effect on their staying time $(Z=57.5, P>0.1$ for position, $Z=11.5, P>0.8$ for rotation direction).

As type-B females were preferred by males, the mating frequencies with type-B and type-O females were compared. Female butterflies were randomly collected in this field from 2000 to 2009 , and the number of spermatophores in their bursa copulatorix was counted.

The results are shown in Table 1. Data were divided into short periods, and compared between types using Wilcoxon's signed-ranks test, with the result that no significant difference was found ( $\mathrm{n}=10, \mathrm{Z}=4.5, \mathrm{P}>0.6)$. In this field, type-B females were approximately twice as abundant as type-O females $(\mathrm{n}=10, \mathrm{Z}=22.5, \mathrm{P}<0.01)($ Table 1$)$.

\section{DISCUSSION}

\section{Can males discriminate between the sexes?}

From the results of the present experiments it is concluded that males of the two theclini species tested, Chrysozephyrus smaragdinus and Neozephyrus japonicus, can discriminate between the sexes of the same species using wing colour and prefer female wings even though these are cryptic in colour. However, this discrimination seems not to be made from a distance, because males approached both models indiscriminately in the first approach. Thus, it is concluded that they first respond to moving objects and then perceive its colour when close to the object.

\section{Can males discriminate between different types of females?}

From the results of the female type discrimination experiment, it is concluded that males of $N$. japonicus can discriminate between females that have a blue patch on their forewing and those that do not. Small differences in wing colour pattern are discriminable by other species: the size of the black spot in Lycaeides idas (Fordyce et al., 2002), UV reflection of white spots in Polyommatus icarus (Knüttel \& Fiedler, 2001), presence of black bars in Eurema lisa (Rutowski, 1977), size of the eyespot (Breuker \& Brake- 
field, 2002) or size of the white pupil in the eyespot in Bicyclus anynana (Butler) (Robertson \& Monteiro, 2005) and presence of yellow bars in Heliconius melpomene (Jiggins et al., 2001).

Neozephyrus japonicus males preferred type-B females. Preference for one female type over another is recorded in other polymorphic species and in such cases the commonest type is preferred, as in Pieris napi (Linnaeus) (Petersen et al., 1951), Colias eurytheme (Kemp \& Macedonia, 2007), Argynnis paphia (Magnus, 1958) and Papilio dardanus Brown (Cook et al., 1994). This is also the case in $N$. japonicus.

Why do males of $N$. japonicus prefer type-B females with a blue patch? One possible explanation is that another related species, Favonius orientalis (Murray), whose females have no blue patch, occur in the habitat of this species and thus males of $N$. japonicus that prefer type-B females would have a lower probability of outcrossing.

Preference for one type of female by males leads to the expectation that females of that type are more likely to be mated, and consequently should contain a higher numbers of spermatophores. This is the case for Colias alexandra Edwards and C. scudderii Reakirt (Graham et al., 1980), but not for $C$. eurytheme (Kemp \& Macedonia, 2007) or $N$. japonicus. As it is known that in territorial species most mating occurs in a male's territory (Wickman, 1985), different types of female $N$. japonicus may have different tendencies to visit the territories of males. This should be examined in a future study.

ACKNOWLEDGEMENTS. We are deeply indebted to Y. Matsui and N. Hirukawa for recommending the fields used in this study.

\section{REFERENCES}

Bitzer R.J. \& SHAw K.C. 1983: Territorial behavior of Nymphalis antiopa and Polygonia comma (Nymphalidae). - J. Lepid. Soc. 37: 1-13.

Breuker C.J. \& Brakefield P.M. 2002: Female choice depends on size but not symmetry of dorsal eyespots in the butterfly Bicyclus anynana. - Proc. R. Soc. Lond. (B) 269: 1233-1239.

Cook S.E., Vernon J.G., Bateson M. \& Guilford T. 1994: Mate choice in the polymorphic African swallowtail butterfly, Papilio dardanus: male-like females may avoid sexual harassment. - Anim. Behav. 47: 389-397.

Cordero C.R. \& Soberón J. 1990: Non-resource based territoriality in males of the butterfly Xamia xami (Lepidoptera: Lycaenidae). - J. Insect Behav. 3: 719-732.

CRANE J. 1955: Imaginal behavior of a Trinidad butterfly, Heliconius erato hydara Hewitson, with special reference to the social use of color. - Zoologica 40: 167-196.

DAVIES N.B. 1978: Territorial defence in the speckled wood butterfly (Pararge aegeria): the resident always wins. - Anim. Behav. 26: 138-147.

Fordyce J.A., Nice C.C., Forister M.L. \& Shapiro A.M. 2002: The significance of wing pattern diversity in the Lycaenidae: mate discrimination by two recently diverged species. $-J$. Evol. Biol. 15: 871-879.

FuJII H. 1982: Adult behavior of Theclini (Lepidoptera; Lycaenidae). - Yadoriga 107/108: 1-37 [in Japanese].
Fukuda H., Hama E., Kuzuya T., Takahashi A., Takahashi M., TanaKa B., TanaKa H., Wakabayashi M. \& Watanabe Y. 1984: The Life Histories of Butterflies in Japan. Vol. 3. Hoikusha, Osaka, 373 pp. [in Japanese, English abstr.].

Graham S.M., Watt W.B. \& Gall L.F. 1980: Metabolic resource allocation vs. mating attractiveness: Adaptive pressures on the "alba" polymorphism of Colias butterflies. - Proc. Natl. Acad. Sci. USA 77: 3615-3619.

IMAFUKU M., Hirose Y. \& TAKEUCHI T. 2002: Wing colors of Chrysozephyrus butterflies (Lepidoptera; Lycaenidae): Ultraviolet reflection by males. - Zool. Sci. 19: 175-183.

Imafuku M., Matsui Y. \& Matsui H. 2006: Flight patterns and mating behavior in a zephyrus hairstreak, Neozephyrus japonicus (Lepidoptera: Lycaenidae). - J. Res. Lepid. 39: 8-17.

Imafuku M., Kubota H.Y. \& Inouye K. 2012: Wing colors based on arrangement of the multilayer structure of wing scales in lycaenid butterflies (Insecta: Lepidoptera). — Entomol. Sci. 15: 400-407.

Jiggins C.D., Naisbit R.E., Coe R.L. \& Mallet J. 2001: Reproductive isolation caused by colour pattern mimicry. - Nature 411: 302-305.

Kemp D.J. \& Macedonia J.M. 2007: Male mating bias and its potential reproductive consequence in the butterfly Colias eurytheme. - Behav. Ecol. Sociobiol. 61: 415-422.

KNÜtTel H. \& FiedleR K. 2001: Host-plant-derived variation in ultraviolet wing patterns influences mate selection by male butterflies. - J. Exp. Biol. 204: 2447-2459.

Lederhouse R.C. 1982: Territorial defense and lek behavior of the black swallowtail butterfly, Papilio polyxenes. - Behav. Ecol. Sociobiol. 10: 109-118.

LEDERHOUSE R.C. \& SCRIBER J.M. 1996: Intrasexual selection constrains the evolution of the dorsal color pattern of male black swallowtail butterflies, Papilio polyxenes. - Evolution 50: 717-722.

Lederhouse R.C., Codella S.G., Grossmueller D.W. \& MaCCARONE A.D. 1992: Host plant-based territoriality in the white peacock butterfly, Anartia jatrophae (Lepidoptera: Nymphalidae). - J. Insect Behav. 5: 721-728.

Magnus D. 1958: Experimentelle Untersuchungen zur Bionomie und Ethologie des Kaisermantels Argynnis paphia L. (Lep. Nymph.). I. Über optische Auslöser von Anfliegereaktionen und ihre Bedeutung für das Sichfinden der Geschlechter. $-Z$. Tierpsychol. 15: 397-426.

OBARA Y. 1970: Studies on the mating behavior of the white cabbage butterfly, Pieris rapae crucivora Boisduval. III. Nearultra-violet reflection as the signal of intraspecific communication. - Z. Vergl. Physiol. 69: 99-116.

Petersen B., Törnblom O. \& Bodin N.-O. 1951: Verhaltensstudien am Rapsweissling und Bergweissling (Pieris napi L. und Pieris bryoniae Ochs.). - Behaviour 4: 67-84.

Robertson K.A. \& Monteiro A. 2005: Female Bicyclus anynana butterflies choose males on the basis of their dorsal UV-reflective eyespot pupils. - Proc. R. Soc. (B) 272: 1541-1546.

RUTOWSKI R.L. 1977: The use of visual cues in sexual and species discrimination by males of the small sulphur butterfly Eurema lisa (Lepidoptera, Pieridae). - J. Comp. Physiol. 115: 61-74.

Rutowski R.L. 1981: Sexual discrimination using visual cues in the checkered white butterfly (Pieris protodice). - Z. Tierpsychol. 55: 325-334.

Rutowski R.L. 1997: Sexual dimorphism, mating systems and ecology in butterflies. In Choe J.C. \& Crespi B.J. (eds): The Evolution of Mating Systems in Insects and Arachnids. Cambridge University Press, Cambridge, pp. 257-272.

Scotт J.A. 1973: Mating of butterflies. — J. Res. Lepid. 11: 99127. 
Scotт J.A. 1974: Mate-locating behavior of butterflies. - Am. Midl. Nat. 91: 103-117.

Shirôzu T. \& SAigusa T. 1980: The "Zephyrus" Hairstreaks of Japan. Lepidopterological Society of Japan, Osaka, 9 pp.

Silberglied R.E. 1977: Communication in the Lepidoptera. In Sebeok T.A. (ed.): How Animals Communicate. Indiana University Press, Bloomington, pp. 362-402.

Silberglied R.E. 1984: Visual communication and sexual selection among butterflies. In Vane-Wright R., Ackery P. \& DeVries P. (eds): The Biology of Butterflies. Academic Press, pp. 207-223.

Silberglied R.E. \& TAYLOR O.R. JR. 1978: Ultraviolet reflection and its behavioral role in the courtship of the sulfur butterflies Colias eurytheme and C. philodice (Lepidoptera, Pieridae). Behav. Ecol. Sociobiol. 3: 203-243.

Stride G.O. 1956: On the courtship behaviour of Hypolimnas misippus L., (Lepidoptera, Nymphalidae), with notes on the mimetic association with Danaus chrysippus L., (Lepidoptera, Danaidae). - Br. J. Anim. Behav. 4: 52-68.

STRIDE G.O. 1957: Investigations into the courtship behaviour of the male of Hypolimnas misippus L. (Lepidoptera, Nymphalidae), with special reference to the role of visual stimuli. - Br. J. Anim. Behav. 4: 153-167.
TAKeuchi T. \& IMAfuku M. 2005a: Territorial behavior of Favonius taxila (Lycaenidae): territory size and persistency. $-J$. Res. Lepid. 38: 59-66.

TAKEUChI T. \& IMAFUKU M. 2005b: Territorial behavior of a green hairstreak Chrysozephyrus smaragdinus (Lepidoptera: Lycaenidae): Site tenacity and wars of attrition. - Zool. Sci. 22: 989-994.

Tinbergen N., Meeuse B.J.D., Boerema L.K. \& Varossieau W.W. 1942: Die Balz des Samtfalters, Eumenis (=Satyrus) semele (L.). - Z. Vergl. Physiol. 5: 182-226.

VANE-Wright R.I. 1984: The role of pseudosexual selection in the evolution of butterfly colour patterns. In Vane-Wright R., Ackery P. \& DeVries P. (eds): The Biology of Butterflies. Academic Press, London, pp. 251-253.

WiCKMAN P.-O. 1985: Territorial defence and mating success in males of the small heath butterfly, Coenonympha pamphilus $\mathrm{L}$. (Lepidoptera: Satyridae). — Anim. Behav. 33: 1162-1168.

WikLund C. 2003: Sexual selection and the evolution of butterfly mating systems. In Boggs C.L., Watt W.B. \& Ehrlich P.R. (eds): Butterflies. Ecology and Evolution Taking Flight. The University of Chicago Press, Chicago, pp. 67-90.

Received July 24, 2014; revised and accepted December 18, 2014 Prepublished online February 3, 2015 